\title{
Developing Jump Serve Exercise Model in Volleyball at Universitas Negeri Padang
}

\author{
Muhamad Sazeli Rifki ${ }^{1 *}$, Ariando Ariston ${ }^{1}$ \\ 1 Faculty of Sport Sciences, Universitas Negeri Padang, Indonesia

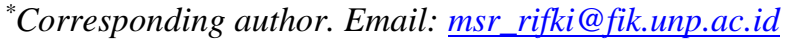

\begin{abstract}
This study concerns on the weaknesses found in floating jump service technique in volleyball training at Universitas Negeri Padang. Thus, this study aims to develop a floating jump service for volleyball. The type of research is developmental research using Borg and Gall model by collecting data on needs analysis which was then used as a basis for making models. The results of the analysis showed that the average percentage of validation results taken from volleyball training experts was $85.07 \%$ and from athletes was $79.97 \%$, $\mathrm{t}$ test $=$ $2,423>\mathrm{t}$ table $=1.708$. The results interpret that: 1 ) the Floating jump serve technique model is in accordance with the principles of floating jump service practice, 2) the model is effective to improve floating jump serve ability, 3) the model is feasible and is ready for mass-produced as a guidance in carrying out the training process especially for floating jump serve.
\end{abstract}

\section{Keywords: Jump Serve, Exercise Model, Volleyball}

\section{INTRODUCTION}

Volleyball is a sport game that has developed and is popular to Indonesian. Even, this game is one of worldwide successful and popular sport which is competitive and recreational. The basic rule of this game is the ball should be bounced back before the ball hits the ground. According to the FIVB official, "volleyball is a sport played by a team on a playing court divided by a net". It means that volleyball is a sport played by two teams in each field that is separated by net. So the core of this volleyball game is the competition between the two teams to keep the ball in the air by bouncing the ball into the air and crossing the ball into the opponent's area in the form of an attack.

Grounding the ball to the opponent's court is a characteristic of volleyball. This is done by tossing or bouncing the ball for three times. The third toss should cross the ball to the receiving opponent's team court. According to "in volleyball, the ball is played or touched for three times at most at the same team and then cross the ball to the opponent in which the ball should pass through over the net and the attack could not be attacked. It means that the goal of the volleyball game itself is tossing the ball through the net to fall on the opponent's area and prevent the same effort from the opponent to do counter attack

Mastering the basic techniques of volleyball is very important, regarding the succeed of high techniques usage will only possible if the basic techniques is quite perfectly performed. The volleyball game is a sport that is played by six people for each team. This game will run well if each player has mastered the techniques, tactics, mental and physical conditions. The volleyball basic techniques are always developed in accordance to thr development of knowledge, technology and other sciences. The basic techniques of volleyball games include: (1) passing (2) smash (3) Service (4) bait (5) dam. One of the advanced techniques is jump serve which is influenced by various factors [2], to improve jump serve skills, it is necessary to consider the dominant factors namely leg muscle explosive power, arm muscle explosive power, coordination and flexibility and confidence (greater path coefficient) [3]. Universitas Negeri Padang is an educational institution that actively participates in fostering and developing volleyball sports. One effort that can be done by UNP is to teach and develop basic volleyball techniques for students through courses or through the Sports Activity Unit. As the matter of fact, several shortcomings were found related to athletes ability to perform floating jump serve technique. This obstacle negatively impact on the achievement of the UNP volleyball. Students are not able to master the technique of playing volleyball well, such as floating jump service. This significantly affects the college prestige.

Based on preliminary study, the athletes have not been able to master the floating jump serve technique in volleyball well. The deficiency can be seen when the athlete performs services, namely: (a) the touch of the ball on the hand or finger cannot be controlled towards the desired target, (b) the ball is hit uncontrollably, (c) the ball goes far or out (d) the ball goes too high up and is touched improperly which consequently often fails to cross the ball into the opponent's court.

In the game of volleyball, one of the difficulties experienced by athletes is the mastery of basic techniques, especially in performing floating jump services. This technique is important to master because this technique is an initial attack in the game of volleyball to ground the ball in the opponent's area or to prevent the opponent to do 
counter attacks. To perform floating jump service, it requires agility, fast movement, good hand eye coordination, and arm and hand strength.

Of the several factors above, the exercise model used is influential. There were several technical training models that could be used in volleyball games. One of them is the floating jump serve technique training model. This exercise is one of the training models that is implemented based on the model that has been prepared. "Development is the systematic use of scientific knowledge directed at the production of materials, systems, or methods including the design of prototypes"[5]

According to the learning model is a plan or a pattern that is used as a guidance in planning classroom learning or tutorial learning [6]. This is in accordance with the opinion of Joyce who states that "Each model guides us as we design instruction to help students achieve various objectives". The purpose of the quote is that each model directs us in designing learning to help students achieve learning goals. [6]. "Models of teaching are really models of learning. As we help students acquire information, ideas, skills, values, ways of thinking and expressing themselves, we also teach them how to learn" [6].

This means that the teaching model is a learning model with that model the teacher can help students get or obtain information, ideas, skills, values, ways of thinking, and expressing ideas themselves. Besides, they are also taught how to learn. A technical training model consisting of several training models has its own advantages for researchers, trainers and athletes. Researchers and Trainers can provide several forms of technical training activities at once in the training process. In addition, the number of models of technical training can also be expected to reduce the saturation of players in carrying out the training process, because players will do different activities for each training model. This will have a positive effect on player motivation in each exercise. In this study the training model provided was not for physical conditions but the model given was a series of service techniques models for floating jump serve.

To produce quality players who can perform floating jump serve perfectly, the coaching should be done well, correctly and directed, so as to provide interesting and dynamic skills for both players and spectators. According to Tant, Greene et al in Marion Alexander (2000: 65-70) floating jump serve has become a dangerous offensive attack for the volleyball team in this era. Good Floating Jump service can produce a number of points during the match. The floating jump service is similar to a jump serve, but this jump service does not use repulsion like a smash and does not rely too much on the leg muscle explosive power. This service is done by jumping with the ball in the air in which it changes its direction continually so it is difficult for the opponent to accept.

Based on the expert's opinion above, floating jump service is one of the core strategy to get the first point in volleyball games to ultimately win the game. To master this technique, it needs to be supported by several factors such as physical, technical, tactical and mental abilities. The physical ability that positively supports is explosive power which is a combination of elements of speed and strength that will produce explosive power in making jumps and punches. This factor is needed in floating jump service where direction and accuracy are needed to put the ball in place which is difficult to be foiled by the opponent.

Another important element that is useful in mastering techniques is coordination. In performing a floating jump service, the player must be able to think and make movements quickly and carefully when having to decide where the ball is directed by considering the opponent's defense pattern. States that what needs to be considered in performing Floating jumps service is the timing, namely the accuracy between the thrown up ball and the server leap that will hit the ball [7].

From the background of the problems described above, researchers wanted to conduct research on developing a floatinf jump service training model for Volleyball in Universitas negeri Padang. It is hoped that the trainers will be helpful in training and athletes in training can be helped. Therefore, research needs to be done with the problems found above.

\section{METHODS}

The method in this research is research and development ( $\mathrm{R} \& \mathrm{D})$. Research and development ( $\mathrm{R}$ and $\mathrm{D})$ is an industry-based development model in which the findings of research are used to design new products and procedures, which there are systematically fields-tested, evaluation [8], the effectiveness of this research is carried out at Gor H. Agus Salim and the Volleyball Sports Arena, UNP on August to September 2018.

The target of this research is UNP Volleyball team. The subject was chosen through purposive sampling, which is based on literacy and in accordance with the objectives

The development procedure in this study refers to the steps as follows: (1) research and information collect; (2) planning stage; (3) developing initial products (develop preliminary from product); (4) preliminary field testing; (5) Main Product revision; (6) main field testing; (7) operational product revision; (8) operational field testing; (9) final product revision; (10) dissemination and implementation [8].

The research instrument is a tool or facility used by researchers in collecting data so that their work is easier and the results are better [9]. To find out the ability of Floating Jump service in volleyball sports in this study, a service technique test was performed, namely Floating Jump service.

The data analysis technique in this study used several formulas as follows:

1) Formulas for processing data per trial subject.

Note:

$$
P=\underline{X} \times 100 \%
$$

$\mathrm{P}=$ Percentage of evaluation result of trial subjects. 
$\mathrm{X}=$ Number of answers to scores by the subjects of the trial.

$\mathrm{Xi}=$ The maximum number of answers in the aspect of assessment by the trial subject.

$100 \%=$ constants.

2) Formulas for processing data as a whole trial subjects.

$$
P=\underline{\Sigma X} \times 100 \%
$$

Note:

$\mathrm{P}=$ Percentage of overall evaluation results of the trial subjects.

$\square \mathrm{X}=$ Total number of answers to the trial subjects in the whole aspect of the assessment.

$\mathrm{Xi}=$ Total overall score of the test subjects in all aspects of the assessment.

$100 \%=$ constants

\section{RESULT}

\section{Model Development Results}

The development of the floating jump service technique training model is to produce an effective and efficient training model, and represent one of the techniques in the game of volleyball, namely Floating Jump. The preliminary study data obtained from the results of library studies will be presented. Furthermore, the needs analysis was carried out through field observations during training activities and matches that were followed by the volleyball team at UNP. Expert validation data were obtained through questionnaires collected from two experts for instrument constructs, four volleyball experts, and twenty-five volleyball athletes. The trial data was collected from 25 athletes through questionnaires. To know the impact of product used as suggested by Borg and Gall, it was necessary to examine the model through experimental method so that the difference test could be carried out by t-test.

Besides, percentage technique was used to process research data from volleyball coach experts, constructor experts, and Volleyball athletes as subjects of trials.

\section{Feasibility Test}

The feasibility test was undertaken though questionnaire consisting of several items related to the applied training model. This test was given to volleyball experts, namely: 1) Zulkarnain, 2) Raifi Andri Ramusli, 3) Dufrizal.

The input and suggestions obtained in the trial are as follows: 1) athletes who cannot perform floating Jump services should be priority, 2) athlete's knowledge of floating jump serve technique must be enhanced.

From the results of the expert validation of three volleyball trainers, the percentage was $85.07 \%$. So that this model was very feasible to use. While the validation of the two expert construct instruments was $80.00 \%$, so the developed model was very suitable to use. Last, the result of the trials of twenty-five volleyball athletes was $79.97 \%$, so that the model is feasible to use.

Expert validation results were tested on athletes with the following results: 1) The variation of this model was stated to have good objectives for improving floating jump serve skills, 2) the variation of this model has good quality in improving floating jump serve in volleyball, 3) the variation of models is not monotonous, 4) Variations of this model are arranged based on the principle of practice from easy to difficult, 5) Variation of this model has good attractiveness to athletes.

\section{Model Effectiveness Test}

To determine the effectiveness of the Floating Jump service training model in volleyball, the researchers implemented the research method of True Experimental Design (Pre Test - Post Test Only Control Design). To test the effectiveness of this model, it followed certain requirements:

\section{a. Prerequisite Test Data Analysis}

The normality test of the data on the research data was carried out as a test requirement. Based on the results of the normality test, L-Calculated was $(0.088)$ and L-Table was $(0.173)$. Hence, it can be said that the data is normally distributed. The final test data showed that L-Calculate value was 0.120 and $\mathrm{L}$-Table value was 0.173 . It can be concluded that the data is normally distributed.

\section{b. T-test}

After the normality testing of the data is completed, the next step is to test it by using t-Test statistics. The results of the author's calculations are presented in the table below:

\begin{tabular}{|c|l|c|l|l|l|}
\hline Group & Treatment & $\mathrm{N}$ & Volume & $\begin{array}{c}\mathrm{T}_{\text {calculatio }} \\
\mathrm{n}\end{array}$ & $\mathrm{t}_{\text {table }}$ \\
\hline $\begin{array}{l}\text { Experim } \\
\text { ent }\end{array}$ & $\begin{array}{l}\text { Floating } \\
\text { jump } \\
\text { service } \\
\text { technique }\end{array}$ & 25 & Score & 2.423 & $\begin{array}{l}1.70 \\
8\end{array}$ \\
\hline
\end{tabular}

Based on the table above, it is known that the tcount value is $2.423>\mathrm{t}$ table 1.708 . Since the $\mathrm{t}$-count value is bigger than the $t$ table, it means that the developed model has a significant influence on athletes' skill. Thus, it can be concluded that the Floating Jump service technique training model has significant effect.

\section{DISCUSSION}

Based on the results of testing and model effectiveness tests, it was known that the floating jump service training model developed in this study is considered to fulfill the requirements to be socialized and applied in volleyball training.

\section{Model Advantages}

The advantages of this service technique training model are because it produces the final product in the form of a service technique training model guidance. With the 
existence of this guidance, it will be useful for volleyball coaches as a guide in carrying out the training process to improve performance effectiveness.

\section{Model Weaknesses}

The weakness of this model is only for floating jump serve technique whereas someone who can play well must master all the principles of technique, tactics, physical and mental conditions. If a volleyball player does not master some of the volleyball techniques, it would be impossible for him to play well.

\section{Model Supporting Factors}

The implementation of the Floating jump service model is strongly supported by several forms of activities including: (1) the Sumatran championship which prepares athletes to perform optimally. With the existence of the Sumatra championship, the Volleyball athletes will be able to participate in the competition. (2) UNP receives athletes / new students every year. In general, this target athlete is practicing volleyball so that he can later become a mainstay player in his area. Based on the data obtained, most of the players who played at the top level, whether it was Livoli Division 1 or National Championship, were mostly from UNP Volleyball graduates. If they can get into the national level, they will most likely be selected to take part in the main division championship.

\section{Model Inhibiting Factors}

The application of this model is not completely run well since it could not be carried out properly. Some inhibiting factors include: (1) the limited number of trainers who have adequate training licenses to train at the volleyball club level in Indonesia. As a reference, a Volleyball coach should have, at least, a C license both national and international (FIVB). (2) training facilities that lack complete inventory such as: volleyball, vests, cones, markers, and a neglected field. (3) there are still some volleyball clubs that do not have their own field to practice.

\section{CONCLUSION}

Based on the results of the analysis of the study, the authors concluded that the training model developed was: a. Effective, it means that the model of the exercise that is applied is in accordance with the actual match situation.

b. Efficient, this model is based on the principles that exist in the phases of volleyball

c. Advantageous, because this model can be taken as a reference for Volleyball coaches in providing training programs.

d. Simple and easy to understand, the training material is seen in terms of ease of use, variety, suitability, and benefits of the exercise itself.

e. An interesting model, the exercise must be interesting, this product is also packaged in a book to make it easier for trainers and athletes to understand the training material and improve the effectiveness of the ongoing training process.

\section{REFERENCES}

[1] Toto Subroto, "Permainan Bola Voli," Bandung; FPOK. UPI, pp, 10-23. 2014

[2] Muhajir, "Pendidikan Jasmani Olahraga \& Kesehatan," J. Tadulako Physical Education, Health And Recreation. Yudhistira; Ghalia Indonesia. 2006.

[3] Rifki, MS, "Jump Serve Volleyball SurveY," 2nd International Conference on Sports Science, Health and Physical Education - Volume 1: ICSSHPE, pp, 71-75.

[4] Ardhana, wayan, "Konsep penelitian pengembangan dalam bidang pendidikan dan pembelajaran,"2002. Malang; J. Universitas Negeri Malang. volume IV Nomor 1. Jan. 2017

[5] Faruq,Muhyi, "Meningkatkan Kebugaran Tubuh Melalui Permainan dan Olahraga Sepakbola," Surabaya; Gramedia. 2008.

[6] Arikunto, S, "Prosedur Penelitian Suatu Pendekatan Praktik,” . Jakarta; Rineka Cipta. 2010

[7] Marion Alexander, "An Anlysis of the Volleyball Jump Serve," J. Of Canadian Sport CenterManitoba Kennedy Center; University of Manitoba. 2000.

[8] Borg, Walter R. dan Gall, Meredith D, "Educational Research: An Introduction," New York; Edition Four. 1983. 